\title{
Wellcome drops TPA
}

\section{Washington}

THE winds of fortune shifted in Genentech's favour last week when the UKbased Wellcome Foundation announced that it is abandoning a six-year research effort into the blood-clot dissolving agent tissue plasminogen activator (TPA), together with studies into novel plasminogen activator (NPA), a 'second-generation' TPA.

Wellcome's decision leaves Genentech, whose Activase is the only TPA drug approved for sale in the United States, with a clear monopoly. Although it faces competition from Hoechst-Roussel Pharmaceuticals' streptokinase and SmithKline Beecham's recently approved Eminase, two thrombolytic drugs unrelated to TPA, Activase has two-thirds of the US market with 1989 sales of $\$ 196.6$ million.

Wellcome had filed with the US Food and Drug Administration for approval of its version of TPA, but a month ago the jury in a district court in Delaware ruled that both TPA and NPA, which are licensed to Wellcome by Genetics Institute, infringed Genentech's US patent rights (see Nature 344, 692; 19 A pril 1990).

Wellcome spokesman Martin Sherwood said the company's decision "was made on a number of grounds", citing a recently published Italian clinical trial that questioned TPA's therapeutic benefit over streptokinase, which is one-tenth of the price (see Nature 344, 183; 15 March 1990), as well as the patent ruling. The company chose not to wait for the preliminary results of the Oxford-based ISIS-III clinical trial, expected later this year, which will provide the first direct comparison of Wellcome's TPA, Eminase and streptokinase.

In what amounts to a strategic shift of resources, Wellcome announced that it is 'stepping up' development of its interferon product, Wellferon, for the treatment of hepatitis B. Wellcome also reaffirmed its commitment to WelGen, a joint mammalian cell production facility that it is developing in conjunction with Genetics Institute. Wellcome hopes to manufacture Wellferon at WelGen when the unit becomes operational in 1991.

When Wellcome entered into the licensing agreement with Genetics Institute, it was thought that TPA might achieve worldwide sales of $\$ 1,000$ million, making it the first blockbuster biotechnology drug. But sales have been disappointing, and according to UK stock analyst Ian Smith it will achieve its early promise only if other medical uses are found. Financially, Smith says, TPA was "only of marginal significance to Wellcome". But stock analyst Peter Drake differs: estimating that only $20-25$ per cent of the throm- bolytic market in the United States has been penetrated, he believes that Wellcome "made this decision based on the patent problem and not on the ultimate size of the TPA market".

Several other companies, including Eli Lilly, Upjohn, American Home Products, Wyeth and Boehringer Mannheim, are thought to be working on second-generation TPAs, but may now have to review

\section{AIDS CONFERENCE \\ French not to attend}

\section{Parls}

THERE will be no official French representation at the Sixth International Conference on AIDS in San Francisco in June because of US Immigration and Naturalization Service rules that anyone testing positive for infection with HIV (human immunodeficiency virus) may be denied entry. French Health Minister Claude Evin told the 43rd World Health Congress in Geneva last week that despite the "good will" of the US authorities, the creation of a special visa for HIV seropositive travellers still does not go far enough.

Although French delegates wishing to attend the conference are not affected by this official stance, the French National Agency for the Fight Against AIDS has arranged for satellite transmission of plenary sessions to be screened in a 900seat hall at the Paris Science and Technology Museum at La Villette.

Peter Coles

their position. Bruce Eisen, chief patent counsel for Genetics Institute, called the jury's decision in the patent case illconsidered, particularly with regard to NPA, which he says "was so different and had such promise of improved properties". If the ruling is interpreted as policy, he says, "there will be no incentive for the betterment of drugs".

Genetics Institute and Wellcome have filed for a reversal of the jury's verdict by the judge, but a ruling is not expected until September.

Diane Gershon

\section{UK NUCLEAR INDUSTRY}

\section{New AEA chairman London}

JOHN Maltby, currently chairman of Burmah Oil, is to take over as chairman of the UK Atomic Energy Authority (AEA) from 1 July.

The appointment will allow the present chairman, John Collier, to concentrate on running Nuclear Electric, the largest of the two new state-owned nuclear electricity generating companies formed earlier this year as a prelude to privatization of the non-nuclear electricity generating industry.

- The AEA has also announced the 1992 closure of its prototype pressure tube boiling water reactor at Winfrith, Dorset. The decision is part of a series of cuts at AEA, forced by the current hiatus in Britain's nuclear programme. The Institution of Professionals, Managers and Specialists, a union which represents scientists and engineers at Winfrith, blames the government's electricity privatization plans for the reactor's closure.

Peter Aldhous

\section{BSE}

\section{Spongiform encephalopathy found in cat}

\section{London}

A POST-mortem diagnosis of spongiform encephalopathy in a British cat has provoked new concern that Bovine Spongiform Encephalopathy (BSE) could be transferred to the human population. The case, in a five-year-old Siamese male, is the first time a spongiform encephalopathy has been found in a cat. But other cases may have gone undetected, being dismissed as general neurological disorders; spongiform encephalopathies can be identified only after death by the characteristic microscopic holes found in infected brain tissue.

Agriculture ministry chief veterinary officer Keith Meldrum says that there is no evidence for a connection with similar diseases in other animals, but speculation is rife that the animal may have contracted the disease by eating pet food containing cattle or sheep tissue infected with spongiform encephalopathy.

The new suggestion of cross-species transmission of spongiform encephalo- pathies has renewed calls for the government to tighten up animal feed regulations, to prevent infective agents entering the human food chain. David Clark, Labour agriculture spokesman, wants a ban on the feeding of sheep and cattle offal to pigs and poultry. So far, research has suggested that these animals are not susceptible to the diseases. The agriculture ministry is to commission research to see if the cat spongiform encephalopathy can be passed to laboratory mice. This should reveal if the cat infection behaves similarly to BSE and scrapie (a similar disease of sheep, thought to be caused by the same infective agent as BSE), which have both been passed to mice.

The Pet Food Manufacturers Association last June advised its members not to use the same cattle central nervous tissue and offal that was later banned for human consumption. But the diseases typically have an incubation period of several years, so other cases may yet emerge, if there is a link with BSE.
Peter Aldhous 